\title{
Policy schemes, operational strategies and system integration of residential co-generation fuel cells
}

\author{
Preprint of an article to appear in the International Journal of Hydrogen Energy, \\ Volume 38, Issue 7, Pages 3050-3063
}

Lise-Lotte Padea*, Sascha Thorsten Schrödera, Marie Münstera, Christoph Birkla,

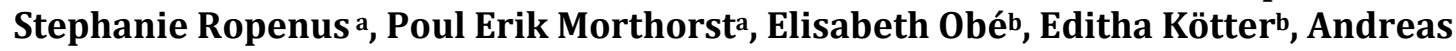
Huberb, Ana Costac, Pablo Kroffc,d

aTechnical University of Denmark,Department of Management Engineering, Energy Systems Analysis, DTU Risø Campus, P.O. Box 49, DK-4000 Roskilde, Denmark

${ }^{b}$ European Institute for Energy Research (EIFER)

Emmy-Noether-Strasse 11, D-76131 KARLSRUHE, Germany

cSIMBIENTE - Engenharia e Gestão Ambiental, Lda.

Avepark - Parque de Ciência e Tecnologia, Edifício Spinpark 4805-017 Guimarães, Portugal

${ }^{d}$ Technical University of Denmark, Department of Chemical and Biochemical Engineering, DTU Risø Campus, P.O. Box 49, DK-4000 Roskilde, Denmark

*Corresponding author:email: llph@dtu.dk; phone: +45 46775194

\begin{abstract}
This study presents a holistic approach for the commercialisation of fuel cells for stationary applications. We focus our analyses on microCHP based on SOFC units fired with natural gas. We analyse the interaction of operational strategies under different ownership arrangements, required support levels and system integration aspects. The operational strategies, support mechanisms and ownership arrangements have been identified through actor analyses involving experts from Denmark, France and Portugal. With regard to operational strategies, the actor analyses led us to distinguishing between a heat-driven strategy, with and without time-differentiated tariffs, and an electricity-price driven strategy for the operation as a virtual power plant. The corresponding support schemes identified cover feed-in tariffs, net metering and feed-in premiums. Additionally, the interplay of the microCHP units with the national energy systems has been analysed. Our main findings are that net metering would be an appropriate tool to support FC based microCHP in Denmark, whereas a price premium would be the preferable tool in France and Portugal.
\end{abstract}

Keywords: stationary fuel cells, microCHP, support mechanisms, operational strategies, systems analysis, natural gas

\section{Introduction}

Since the beginning of 1990s, the problem of climate change has been a key driving factor behind the development of not only the European Union (EU) energy policy, but also the energy policies adopted by the member states. However, in a European context the issue of security of supply plays a major role besides climate change and energy price considerations. As an exemplary 
member state initiative, the Danish Government has recently launched a long term energy strategy with the main objective of making Denmark independent of fossil fuels in the long term time perspective, thereby not only improving the security of energy supply, but also significantly reducing greenhouse gas emissions.

The EU has an overall objective of achieving 20\% savings on primary energy sources by 2020 . However, by 2011 it seems that not much more than half of this amount will be reached according to the EU Commission's latest estimates [1]. Thus, new energy conservation initiatives are required. One of the most promising areas is the exploitation of combined heat and power (CHP). As mentioned in [1], "High-efficiency cogeneration (CHP) and district heating and cooling has significant potential for saving primary energy which is largely untapped in the Union", paving the way for more CHP plants.

However, in some member states, e.g. Denmark, the development of both largescale and small-scale (decentralised) CHP has been a cornerstone in the energy policy for several decades, implying a highly efficient power and heating supply in combination with an extensive developed district heating network. Scenarios for 2060 covering almost 100\% of energy demand with renewable energy sources [2] show that CHP technologies could play a considerable role in Germany by 2060, whereas the Scandinavian countries tend to rely more on heat pumps. The use of fuel cells and hydrogen storage at different points in the energy system can contribute considerably to manage wind power fluctuations. The composition of the CHP power plant park is expected to change significantly within the next years because of two issues: 1) the large-scale power plants are gradually being phased out mainly due to the introduction of massive amounts of wind power and 2) the utilisation of small scale CHP-plants has exploited the heating market to the limits and further expansion potentials are limited. Thus, not much room is left for the development of CHP in Denmark. New market segments have to be developed if further efficiency improvements are to be gained through CHP.

One of these potential new market segments is associated with the introduction of fuel cells for micro CHP (abbreviated as microCHP in the following). In the long run, they could play a considerable role in building national energy systems with low $\mathrm{CO}_{2}$ emissions [3], especially, as the variability of fuels is one of the major advantages of fuel cells [4]. As stressed in the article, framework conditions and policy goals are decisive. This applies also to technology-specific targets and support as illustrated by the successful deployment of e.g. wind and solar power over the last decade. With regard to microCHP, first suggestions on how this could be implemented are provided in [5][6]. Erdmann [7] analyses the possible future market penetration of residential solid oxide fuel cell (SOFC) applications in Germany. Erdmann's studies cover both natural gas and heating oil as possible fuels. He concludes that the overall potential is promising although future cost decreases and a well-functioning fuel cell industry and network are important. The study is based on cost assumptions that are still ambitious from today's point of view.

Depending on the economic framework and ownership of the microcHP units, different operational strategies can evolve (see e.g. [8][9]). These are crucial for prioritisation in technological development: depending on the results and recommendations of such studies, stack developers may decide to focus on e.g. 
longer lifetimes or modulation capabilities. A technical analysis on residential cogeneration with a low-temperature Proton exchange membrane fuel cells (PEMFC) complements the above analyses [10].

Mathiesen and Østergaard [4] find that modulation capabilities play an important role in systems with a high penetration of fluctuating renewable energy sources because the SOFC units can provide balancing energy. Conversely, Staffell et. al. [11] stress the importance of long product lifetimes. Yet another option is variable heat-to-power ratios for single dwellings [12]. Comparing several competing microCHP technologies with currently dominant technologies, the importance of cost decreases is stressed by De Paepe [13]. Hawkes et. al. [14] performed a technical-economic study considering a number of constraints like start-up costs, degradation, and minimum operation time. In an application of their model, Hawkes et. al. [15] stress the importance of degradation over lifetime: high degradation rates can undermine the marginal generation value and $\mathrm{CO}_{2}$ emission reductions over the lifetime, though this effect is less pronounced for SOFC than for PEMFC systems. Another interesting point for sustainable energy scenarios is biogas application in microCHP fuel cells: a technical study on how biogas as a fuel affects the operation of a microCHP SOFC system is provided by [16]. In all of their analysed cases, the units can cover demand at different fuel utilisation ratios, although yielding different voltages.

Based on learning curves, possible future price levels have been computed by Staffell and Green [17] who stress the importance of support if a considerable market penetration is to be reached before 2025 .

This study presents the main results of the FC4home project (www.fc4home.com). It contributes to the field by analysing both the economic incentives for private investors and the system consequences of fuel cell based microCHP. In doing so, the FC4Home project aims to assess the relevant support schemes as well as support levels for fuel cell based microCHP using Denmark, France and Portugal as exemplary country cases. From a technical point of view, the project focuses on the SOFC technology operated on natural gas as a fuel. This allows the integration in existing fuel infrastructure, which does not exist for hydrogen yet. Moreover, the additional fuel reformer required for a PEMFC can be spared [7]. The policy framework that is analysed in this study could apply generally, i.e. it may also include PEMFC if these can provide a competitive solution for residential applications. At a later point in time, the technological development that happened with the most accessible option in the near future, namely natural gas, will help pave the way for a possible transition to hydrogen as a fuel.

This article is structured as follows: with the point of departure in a SWOT analysis (Section 2), an actor analysis (Section 3) as well as a survey of the support schemes most frequently applied in the EU countries (Section 4) we define a range of combinations of ownership arrangements, control strategies and support schemes and determine the relevant combinations for Denmark, France and Portugal (Section 5). Based on electricity and heat consumption profiles for two house types we establish the most relevant support scheme for each respective country. Furthermore, we perform a system analysis determining the cost effects, changes in fuel consumption and related $\mathrm{CO}_{2}$ emissions in the three countries as a result of implementing each of the 
combinations for each country. The models applied for the analyses are presented in Section 6 and the results from the analyses are presented in Section 7. We discuss the results as well as the basic assumption for our analyses in Section 8 and, finally, Section 9 concludes. Our study contributes to the research in the field by analysing the economic incentives for private investors as well as system effects of fuel cell based microCHP. To our knowledge such analyses have not been carried out previously.

\section{SWOT analysis}

MicroCHP fuel cells face a challenging and competitive situation. Their main advantages and deficiencies have been analysed according to the PESTLE framework, i.e. with regard to Political, Economical, Social, Technological, Legislative and Environmental aspects. The most important points identified are then scrutinised by applying a SWOT analysis, presented in the following. This chapter is mainly based on a report by [18], where further details can be found. The presented results have been updated to reflect current developments.

Table 1: Main results of the SWOT analysis for the regarded countries

\begin{tabular}{|c|c|c|c|}
\hline & Denmark & France & Portugal \\
\hline Strengths & $\begin{array}{l}\text { - High R\&D } \\
\text { investments and } \\
\text { budget for fuel cell } \\
\text { and microCHP } \\
\text { projects } \\
\text { - Rich mix of } \\
\text { decentralised and } \\
\text { centralised energy } \\
\text { production } \\
\text { technologies } \\
\text { - Increasing social } \\
\text { acceptance }\end{array}$ & $\begin{array}{l}\text { - Existing national } \\
\text { promotion of CHP } \\
\text { technologies } \\
\text { - R\&D investments for } \\
\text { fuel cell and } \\
\text { microCHP projects }\end{array}$ & $\begin{array}{l}\text { - Existing national } \\
\text { promotion for } \\
\text { renewable-based } \\
\text { technologies }\end{array}$ \\
\hline Weaknesses & $\begin{array}{l}\text { - Lack of specific } \\
\text { regulation }\end{array}$ & $\begin{array}{l}\text { - Lack of specific } \\
\text { regulation } \\
\text { - Increasing the gas } \\
\text { consumption }\end{array}$ & $\begin{array}{l}\text { - Lack of specific } \\
\text { regulation } \\
\text { - Centralised energy } \\
\text { markets } \\
\text { - Low consumer } \\
\text { awareness }\end{array}$ \\
\hline Opportunities & $\begin{array}{l}\text { - Long-term EU policy } \\
\text { goals could be } \\
\text { supported by fuel cell } \\
\text { microCHP }\end{array}$ & $\begin{array}{l}\text { - Flexibility and variety } \\
\text { of fuel cell } \\
\text { technology } \\
\text { - Strong public } \\
\text { awareness on } \\
\text { positive technology } \\
\text { impacts }\end{array}$ & $\begin{array}{l}\text { - Energy companies' } \\
\text { investments in mCHP } \\
\text { technologies under } \\
\text { the MyEnergy service } \\
\text { scheme }\end{array}$ \\
\hline Threats & $\begin{array}{l}\text { - Support for a non- } \\
\text { renewable technology } \\
\text { politically doubtful } \\
\text { - Heat pumps as a } \\
\text { partially competing } \\
\text { technology viable } \\
\text { already today }\end{array}$ & $\begin{array}{l}\text { - Historically strong } \\
\text { focus on nuclear } \\
\text { power } \\
\text { - Target to reduce the } \\
\text { CO2 emission by } \\
\text { factor } 4 \text { incompatible } \\
\text { with the increase of } \\
\text { the emissions due to } \\
\text { the growth of natural } \\
\text { gas consumption }\end{array}$ & $\begin{array}{l}\text { - Limited fuel cell R\&D } \\
\text { project funding } \\
\text { - Difficulties to access } \\
\text { monopolist } \\
\text { Portuguese grid } \\
\text { - Reluctance of } \\
\text { consumers }\end{array}$ \\
\hline
\end{tabular}


All countries share the common characteristics that fuel cells can support common EU policy goals, but are dependent on specific national policy implementation. This holds especially for security of supply in the mid-term horizon and for the transition towards a renewable-based energy sector in the long run. Table 1 gives an overview of the main country-specific outcomes of the SWOT analysis. The main differences to be highlighted are differences in fuel cell specific R\&D investment, historically differently developed energy sectors and differences in consumer awareness and attitude towards this technology. Already today in Denmark, heat pumps are being installed to replace oil furnaces. Like other alternative heating technologies competing with fuel cells, they are currently considerably cheaper and could therefore take the fuel cell's potential role before these can become more price-competitive.

Returning to the single points of the PESTLE framework, technological progress and simultaneous unit cost decreases are crucial to achieve a considerable market penetration. However, this needs to be accompanied by increased public awareness and adequate political support with a focus on ensuring that the technology is in the long run deployed in an environmentally friendly way, e.g. through switching to biogas as a fuel.

\section{Actor analysis}

The expectations about the future role as well as the perceptions of the chances of fuel cell based microCHP technology are crucial for possible market penetration. In order to elucidate the expectations of national stakeholders in the three countries considered in the analysis, an actor analysis was conducted. A list of national experts was questioned concerning the future scenarios for fuel cell based microCHP in Denmark, France and Portugal. The analysis was carried out by means of focus group discussions and questionnaires. The analyses provided information about three important aspects of fuel cell based microCHP:

1. the future role of the technology

2. possible ownership arrangements

3. support schemes.

The actor analysis overall reveals that national experts expect that fuel cell based microCHP will have the role of a niche technology mainly in the rural areas in Denmark and for multi-storey buildings in France whereas in Portugal, fuel cell based micro cogeneration seems to have few chances in general. The experts expect fuel cells to play the role as balancing grid and flexible demand. Furthermore, in Denmark fuel cells could serve the purpose to phase out individual oil boilers. The main challenge for fuel cell based micro cogeneration is the vague reliability as well as competing technologies. In Portugal fuel cells in general have a poor reputation. Furthermore, fuel cells are not necessarily "green", i.e. they may be running on fossil fuels e.g. natural gas. However, this problem could be solved for specific applications by assuming the application of biogas as the future fuel.

When it comes to the expected ownership arrangements in Denmark, the experts expect the fuel cells to be owned by households and operated by either the households themselves or an external service provider - e.g. an electricity 
company. This is motivated by the expectations that some users are "homo oecologicus activus", i.e. consumers who consider themselves as active promoters of environmental protection and others are "homo oeconomicus", i.e. users who, given the information at hand, are aiming to maximise their own economic benefits and minimising resources and may choose an energy service provider [19]. Due to tradition, in France the fuel cells are expected to be owned and run by households. As the reluctance is most profound in Portugal, the expectation is that the ownership arrangement should be the one leading to the least risk and the lowest transaction and maintenance costs for the households, i.e. the fuel cell will be owned and operated by service providers.

Finally, regarding support schemes, the expectation of the experts in Denmark is that a price premium will be used to support the grid balancing aspect of installing the fuel cells. As for France, a combination with investment support was perceived as an attractive solution. In Portugal the expectation is that a price premium in combination with a tax reduction will reduce the risk while simultaneously reflecting the market price and thus making it attractive to companies. However, the authors would like to stress the fact that these findings are based on a small number of participants per country, so results are not necessarily representative.

\section{Support schemes}

The choice of support scheme is dependent on a project developer's decision to invest in a new technology, which again is affected by the costs and risks of the investment. Normally we distinguish between investment support - such as capital grants - and operating support - such as feed in tariffs, price premiums or quantity-based support schemes, e.g. quota systems (Figure 1).

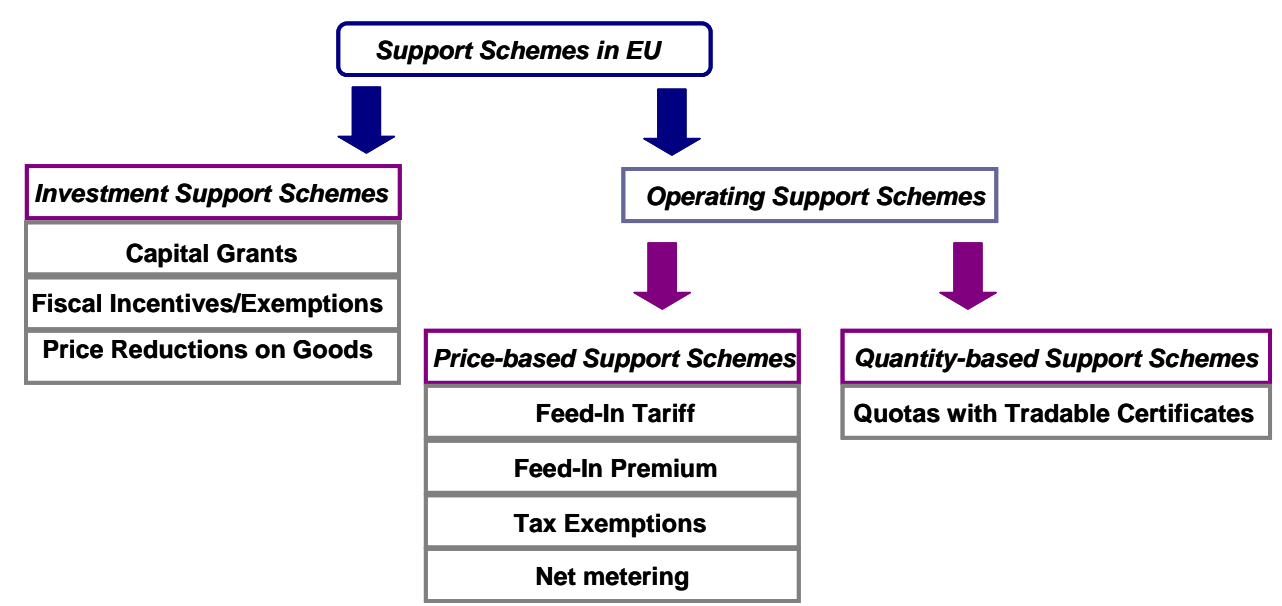

Figure 1: Support schemes, source: [20]

Normally, in the early stages of the technology's development, the risks associated with the technology itself as well as the risks and associated costs are very high. Thus, a high degree of financial certainty might induce investments in the technology. Along with the decrease in the technological risk, as technology matures, operational support schemes may be considered. The more the technology reaches market competitiveness, the more related to the market the support scheme will be, i.e. in the beginning a fixed feed in tariff will be applied 
assuring the investor a fixed price per $\mathrm{kWh}$. At a later stage, the investor will receive a price premium on top of the electricity price exposing the investor to fluctuations in the market price. Finally, when the technology has reached the level of maturity that corresponds to competitiveness, it will be market risk that dominates the technology.

Assuming the investment to be made by a small private investor such as a household, the fuel cell microCHP technology is characterised by high technological risk, which makes the regulator choose investment support. However, for other kinds of investors with higher demand for rate of return and more capital funds available, economies of scale could be realised by a single actor purchasing a large number of units. For this kind of professional investor, it would be more relevant for the regulator to introduce a price premium.

\section{Scenario definitions}

The stakeholder analyses and the survey of the support schemes led to the following definitions of ownership opportunities, control strategies and possible support schemes:

\section{Ownership}

I. Consumer plug and play: The consumer buys the fuel cell, installs and operates it.

II. Company control: The fuel cell is run by a company - e.g. an electricity or gas provider - and installed in the individual households. The fuel cell is either owned by the household or the company operating it.

\section{Control strategy}

I. Thermal control: the fuel cell is operated with the purpose of fulfilling the heat demand of the household. The household is equipped with a heat storage enabling a longer uninterrupted runtime in order to reduce the number of start-ups of the fuel cell. In the thermal control strategy cases, we assume a $1 \mathrm{~kW}$ fuel cell with an electrical efficiency of 40 percent and an overall efficiency of 90 percent combined with a heat storage of $200 \mathrm{l}$. The assumed efficiencies are in line with e.g. [11][21][22].

a. One import tariff: The household faces the same import tariff 24 hours a day.

b. Peak period: The household faces two different end consumer prices dependent on whether it is peak or off peak hours. When there is the opportunity to shift the electricity generation of the fuel cell, the control strategy shifts the running hours to the peak periods in order to decrease the amount of electricity bought from the grid during the high price period of imported electricity or to increase the amount of electricity exported electricity during this time of high price imported electricity. The $200 \mathrm{l}$ heat storage can be used to shift the operating hours of the fuel cell.

c. Virtual power plant: the fuel cell is assumed to be a part of a virtual power plant. [23] defines this as "a cluster of distributed electricity generation units, controlled and operated by a central entity using integrated software. This allows power generation to be 
modulated up or down to meet peak loads and balance intermittent power from wind or solar, with higher efficiency and more flexibility than large centralised power stations" and elaborates on a Dutch test case with a high-efficiency SOFC fuel cell. The control strategy is designed only to take the market price of electricity into account. Thus, the fuel cell is operated independently of the heat demand of the household. We assume that excess heat can be blown off costless. In the virtual power plant cases we assume a $2 \mathrm{kWe}$ fuel cell with an electrical efficiency of 60 percent and an overall efficiency of 80 percent, which is approximately in line with the currently available BlueGen system by the manufacturer CFCL [24]-[25].

d. Day-ahead market: The electricity is sold on the day-ahead market.

e. Regulating power market: The electricity is sold on the regulating power market. The fuel cell is assumed to run 50 percent load as default in order to be able to up-regulate as well as down-regulate. The seller of the electricity receives the regulating power price as well as the stand-by payment.

\section{Support scheme}

a. Net metering: in case of net metering, the electricity meter is able to run backwards when the electricity production from the fuel cell exceeds the electricity consumption of the household. This way, the household receives the difference between the end consumer price and the market price of electricity as an economic benefit. The observed/analysed time period is one year. Net metering is only used for the thermal control scenarios.

b. Feed in tariff without self consumption: in this case, the household is literally equipped with two electricity meters - one measuring the electricity consumption and one measuring the electricity production of the fuel cell, which is all sold to the grid. For the electricity sold to the grid, the household receives a fixed tariff per $\mathrm{kWh}$. The pure feed-in tariff is only used in combination with the thermal control strategy.

c. Feed-in tariff, self-consumption: in this case, the household is also equipped with two electricity meters - one measuring the electricity consumption and one measuring the electricity production of the fuel cell. In the situations when the household consumes electricity at the same time as the fuel cell produces electricity, the household consumes it itself. When the electricity production exceeds the consumption, the electricity is sold to the grid for which the household receives a feed-in tariff per $\mathrm{kWh}$. When the electricity consumption exceeds the production, the household imports electricity from the grid for which they pay the end consumer price. This support scheme is only used in combination with the thermal control strategy.

d. Price premium: in this case all the electricity is sold to the grid. The seller receives a fixed premium on top of the market price of electricity, either the spot market price or the regulating market price dependent on the control strategy. The price premium is only used in case of virtual power plant control strategy. 
The resulting scenario tree is illustrated in Figure 2 and displays eight possible scenarios.

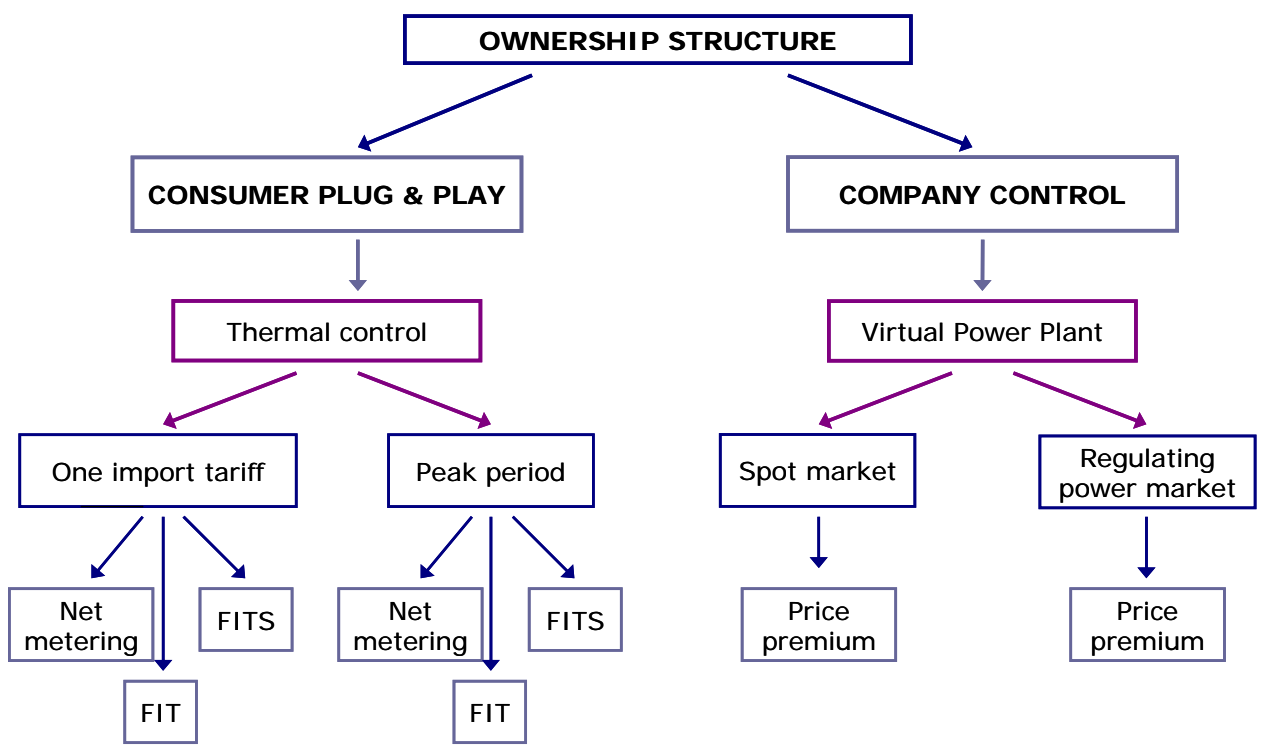

Figure 2: Combinations of ownership structure, control strategies and support schemes

\section{Modelling approach}

In order to fulfil the objective of the analyses three models were applied: a technical model for the optimisation of the control strategy, an economic model to determine the necessary support levels, and an energy system model to analyse the effects on the energy system. The connection between the three models is illustrated in Figure 3.

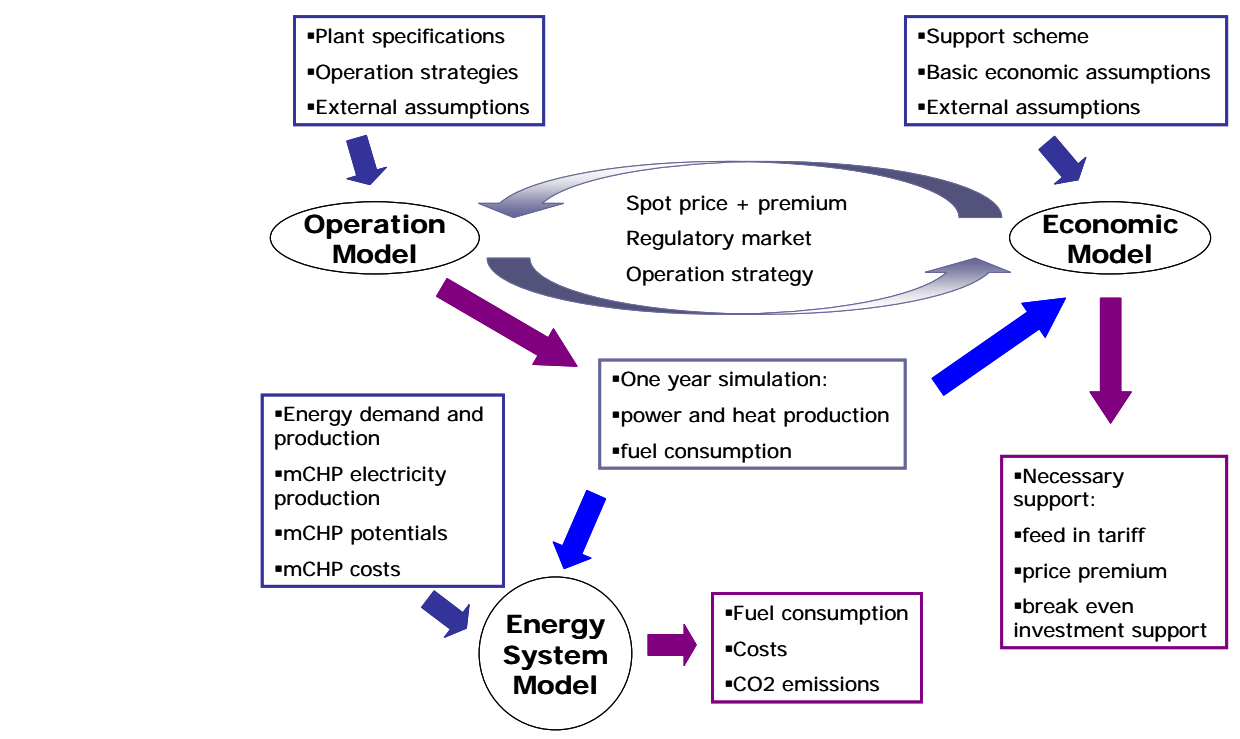

Figure 3: Modelling approach 


\subsection{The operation model}

The system border of the operation model is the heat and electricity supply of a single dwelling. Regarding heat supply, this represents the interplay of the microCHP unit and the conventional gas boiler. Regarding the electricity supply, this covers the electricity demand profile [26].

The inputs to the technical model are mainly the energy needs of the houses and the technical characterics of the mCHP and the heat storage, such as nominal power electrical, thermal efficiencies and the volume of the heat storage.

For operational strategies taking power price signals into account, such as peak tariffs or fluctuating hourly prices for virtual power plants, this financial data is also provided as input. The model operates on a 10-minute basis and according to the desired operational scheme: it can either be operated to cover heat demand the cheapest way possible, calculate heat and electricity supplies for net metering and self-consumption tariffs, or optimise operation based on electricity prices only if it is used as a VPP. Thus, for the different regulatory scenarios, different techno-economic criteria apply.

\subsection{The economic model}

The inputs to the economic model are specifications of support schemes, e.g. feed-in tariff, price premium etc., basic economic assumptions such as the discount rate and inflation, fuel and electricity prices and inputs from the technical model such as electricity and heat production and fuel consumption [27]. Based on this information, the model determines the total costs and total income from the fuel cell. Dependent on the control strategy and support scheme in question, the economic model determines the necessary support, defined as the support level giving appropriate economic incentives for private actors to invest in the technology. The necessary support is given by the necessary feed-in tariff or price premium or the break-even investment support.

In the virtual power plant scenarios, the chosen price premium affects the operational strategy which again affects the optimal price premium. In order to establish the optimal operational strategy and support scheme, iterations between the technical model and the economic model took place.

\subsection{The energy system model}

National energy system analysis was performed using the STREAM model [28]. STREAM is an energy system modelling tool which balances hourly energy demands and supplies within the time frame of one year and delivers results on energy production, fuel consumption (resource utilisation), emissions and costs. It is typically used for predictive or explorative analysis of national energy systems but not capable of system optimisation.

The inputs to the energy system model consist of data representing the future national energy systems, mainly found from the DG-TREN forecast of 2009 [29]. Furthermore, hourly time series for the national electricity demands and wind power production from ENTSO-E, the European Network of Transmission System Operators (TSOs) [30] and from the national TSOs were used. Finally, potentials for installing natural gas based microCHPs were estimated for each country, and results from the technical model regarding hourly microCHP electricity production were used along with annualised microCHP costs [27]. The 
outputs from the model consist of the national fuel consumption and costs related to energy production. Energy system analysis facilitates identification of the combined system effects (e.g. marginal $\mathrm{CO}_{2}$ emissions) of implementing an energy technology into an energy system ([31][32]). These may be used to compare energy technologies directly or serve as input to complete life cycle assessments. The STREAM model is here used to identify the $\mathrm{CO}_{2}$ emissions from the total energy system with and without implementation of the fuel cells. Finally, the model shows the resulting share of condensing power and the enforced electricity export.

\subsection{Data}

The price assumptions are illustrated in Table 2. As the Table shows the end consumer electricity price of Denmark is three times as high as the end consumer price in France and twice as high as the one in Portugal. Furthermore, the Table shows that the gas price in Denmark is approximately twice as high as the gas price in the two other countries. Finally, we see that the average power price in Portugal is significantly higher than the one in Denmark and France.

\section{Table 2: Price data}

\begin{tabular}{llccc} 
Energy prices & Unit & Denmark & France & Portugal \\
\hline Fuel cost, end consumer gas price & $€ / \mathrm{kWh}$ & 0.11 & 0.0579 & 0.0629 \\
Electricity consumer price & $€ / \mathrm{kWh}$ & 0.3 & 0.1145 & 0.15035 \\
Electricity consumer price, day & $€ / \mathrm{kWh}$ & & 0.1275 & 0.1489 \\
Electricity consumer price, night & $€ / \mathrm{kWh}$ & & 0.0864 & 0.08077 \\
Power Exchange Price (average) & $€ / \mathrm{kWh}$ & 0.057 & 0.043 & 0.070 \\
\hline
\end{tabular}

Source: [27]

In the analyses we have considered two types of house, an old house and a new house. The heat consumption is approximately the same in the three countries, approximately $20000 \mathrm{kWh} /$ year for an old and $10000 \mathrm{kWh} /$ year for a new house, respectively. The heat consumptions cover hot water supply as well as room heating. The annual electricity consumption is not dependent on whether the house type is old or new ([26],[33]) and amounts to approximately 3700 kWh/year in Denmark and 3000 kWh/year in France and Portugal.

\section{Results}

\subsection{Operational strategies}

In this section, we will turn towards the results of the operational strategies in greater detail. Comparative results for all countries can be drawn from Section 7.2 because they constitute the input for the financial calculations. Here, we focus on examples and sensitivity analysis for the Danish country case. This is based on [26], where comparative illustrations and explanations can be found for other Danish cases and with regard to France. 


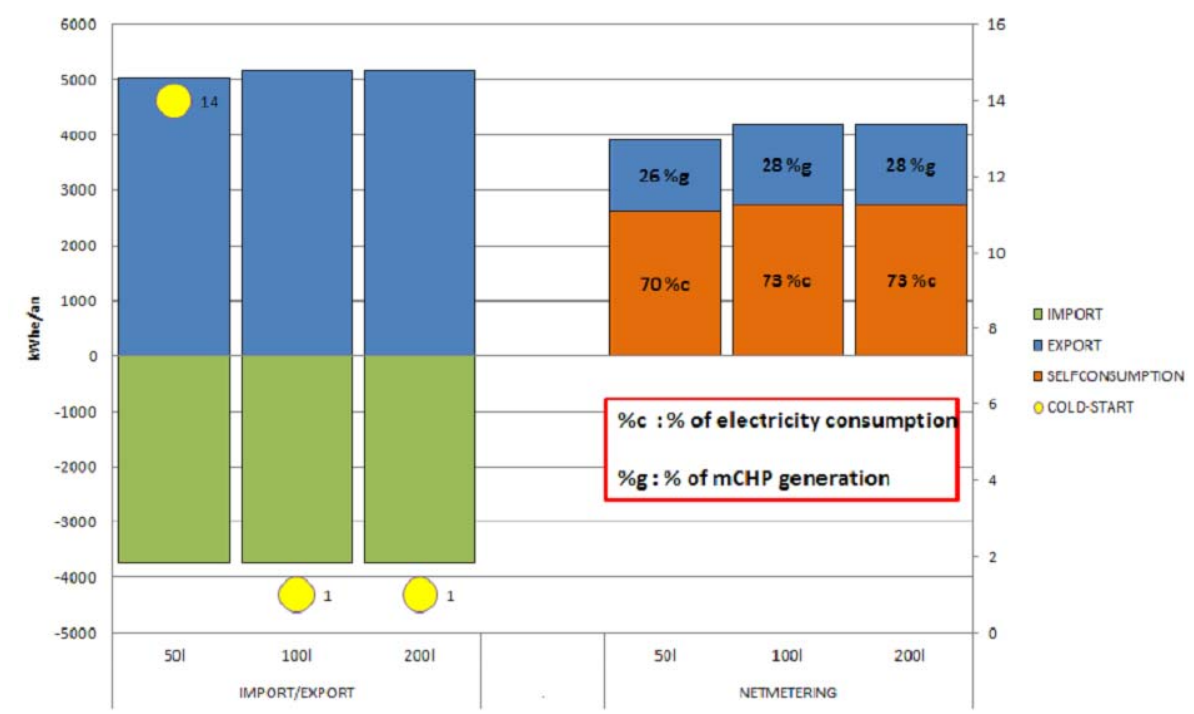

Figure 4: Electricity exchange scenarios for an old Danish house with a heat-driven microCHP fuel cell, source: [26]

Figure 4 gives the results for a heat-driven $1 \mathrm{~kW}$ el microCHP unit in an old Danish house. In the left part of the Figure, electricity imports from the grid and exports to the grid are illustrated under a feed-in tariff. As all generation is sold to the grid, the import from the grid is independent and thus, constant. It is remarkable that an increase of the available heat storage size from 501 to 1001 only increases the annual generation amount marginally. Contrarily, the number of cold-starts requires considerable changes: it is reduced from 14 to one cold start during the course of the year. Increasing the storage size to 2001 does not lead to any further changes.

Next, let us regard the net metering case which is illustrated in the right part of the Figure. The amount of simultaneously self-consumed electricity increases marginally if the storage size is modulated from 50 to 1001 . This covers $70 \%$ or $73 \%$ of the house's electricity consumption, respectively. The remainder of the generation is exported to the grid, constituting approximately $27 \%$ of the microCHP generation.

The operation pattern of the $2 \mathrm{~kW}_{\text {el }}$ unit in the Virtual Power Plant case depends on the price premium. First, we consider operation during an exemplary summer day, before turning to aggregate results. Figure 5 shows the heat generation patterns for a price premium of 0 and $5 \mathrm{ct} / \mathrm{kWh}$, respectively. For a non-existing price premium (left), the microCHP unit does only operate during the typical midday price peak, while the remainder of thermal demand is covered by the natural gas boiler. For a price premium of $5 \mathrm{ct} / \mathrm{kWh}$ (right), the income from electricity sales is so high that the microCHP fuel cell operates permanently at full power, except a switch-off at low prices during early morning hours. The natural gas boiler only needs to produce a small amount in few hours to cover the remaining heat demand. In both cases, heat demand is sufficiently high and the storage sufficiently large so that no heat generation from the microCHP fuel cell has to be discarded. 


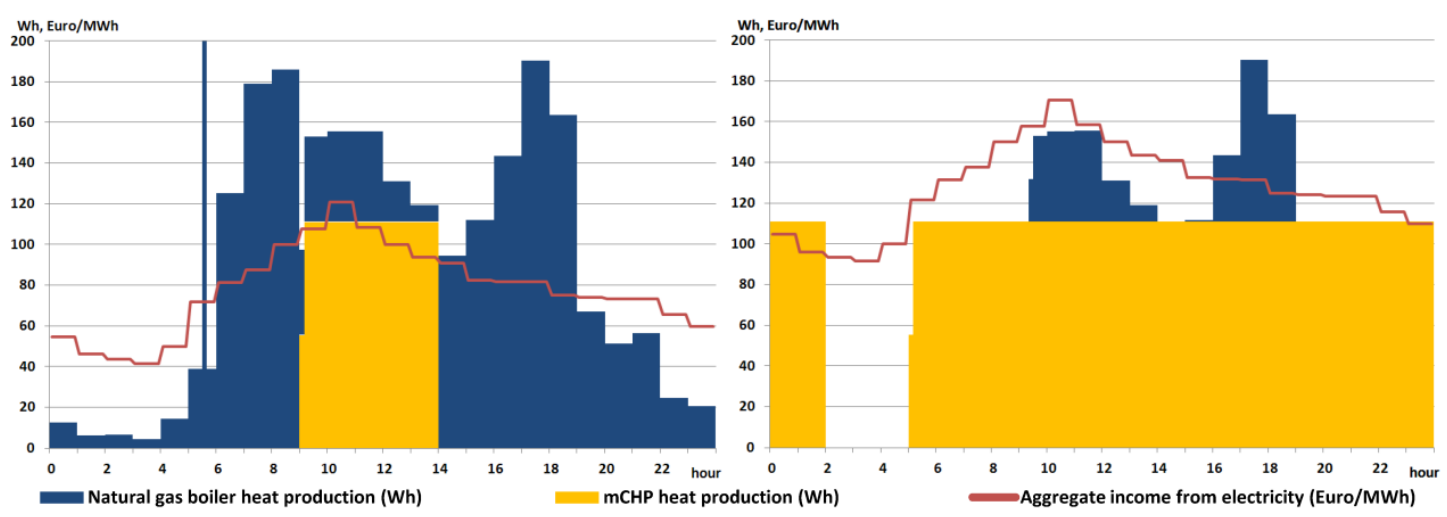

Figure 5: Operational examples under different price premiums in the Virtual Power Plant case; left: premium $0 \mathrm{ct} / \mathrm{kWh}$, right: premium 5 ct/kWh

Figure 5 illustrates the aggregate results for different price premium levels. While export, i.e. generation is only profitable in few hours if the support level is at $0 \mathrm{ct} / \mathrm{kWh}$, the $2 \mathrm{~kW}$ unit generates over $11300 \mathrm{kWh} / \mathrm{a}$ if the premium level is set at $5 \mathrm{ct} / \mathrm{kWh}$. A premium level of $10 \mathrm{ct} / \mathrm{kWh}$ and higher corresponds to almost permanent or permanent operation. It is in line with these elaborations that the average electricity price in operation hours decreases from $11.82 \mathrm{ct} / \mathrm{kWh}(118.2$ Euro/MWh) to about $5.6 \mathrm{ct} / \mathrm{kWh}$, i.e. the marginal benefit decreases. The presented results show also a very diverse picture with regard to cold starts: levels below 50 cold starts per year are only achieved for price premiums from $10 \mathrm{ct} / \mathrm{kWh}$ upwards. This amount is reduced considerably for lower as well as for higher support levels regarded. At a price premium level of $10 \mathrm{ct} / \mathrm{kWh}, 31$ annual cold starts are required despite the almost permanent operation.

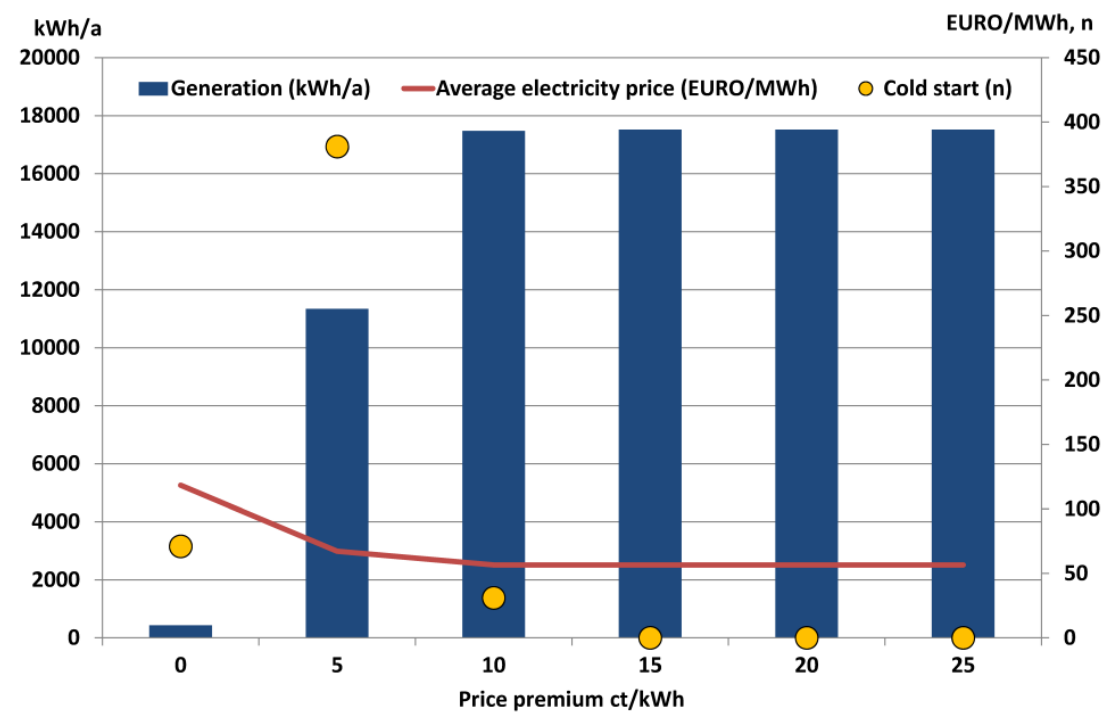

Figure 6: Characteristics of operational strategies as a Virtual Power Plant on the spot market for an old house in Denmark

The main results for the other focus countries France and Portugal are as follows: they are comparable for the heat-driven cases. The microCHP unit produces about $1000 \mathrm{kWh}$ more per year than in Denmark. For the case with partial self-consumption in France, which would be in line with existing 
legislation, the operational pattern corresponds to the feed-in tariff regime. In this case, less electricity is bought from the grid because $56 \%$ of electricity consumption can be covered by microCHP generation. A higher number of generation hours is achieved in France than in Denmark for the same price premium if the microCHP unit is operated as a VPP.

\section{2. $\quad$ Support mechanisms}

The actor analysis, the analysis of support schemes as well as the scenario definitions has led to combinations of control strategies and support schemes for the three countries (See Appendix A). All scenarios were carried out for an old and a new house and in all cases we assume a SOFC.

The most promising scenarios with respect to support levels are thermal control combined with net metering in Denmark, whereas for France and Portugal the virtual power plant - spot market seems most attractive. In the following the results for these three scenarios are presented. For a thorough presentation of all the considered scenarios see [27].

\subsubsection{Denmark}

If the fuel cell is operated according to thermal control, the number of full load hours is approximately 5000. The heat demand covered by the fuel cell amounts to approximately one third or two thirds of the heat demand in an old or a new house, respectively (Table 3 ).

\section{Table 3: Thermal control - Denmark}

\begin{tabular}{lll} 
& New house & Old house \\
\hline Electricity production & $4957 \mathrm{kWh} / \mathrm{year}$ & $5432 \mathrm{kWh} / \mathrm{year}$ \\
Electricity export (net metering) & $1220 \mathrm{kWh} / \mathrm{year}$ & $1696 \mathrm{kWh} / \mathrm{year}$ \\
Full load hours & 4957 & 5432 \\
Heat demand covered by FC & $60 \mathrm{pct}$. & $35 \mathrm{pct}$. \\
Break even investment costs & $4209 € / \mathrm{kW}$ & $4905 € / \mathrm{kW}$ \\
\hline
\end{tabular}

Source: [27]

The breakeven investment of $4200 € / \mathrm{kW}$ and $4900 € / \mathrm{kW}$ in the new and old house, respectively, roughly equals the investment level assumed in the analyses, i.e. $5000 € / \mathrm{kW}$. This indicates that net metering in combination with a consumer owned fuel cell operated as thermal control is an attractive incentive scheme for residential fuel cells in Denmark. This result relies on the assumption that the household receives the full end consumer price for the entire amount of electricity produced - indirectly for the amount they consume themselves and directly for the amount exceeding the electricity consumption and sold to the grid.

\subsubsection{France}

When the fuel cell is operated as a part of a virtual power plant on the spot market in France, there is no difference between an old and a new house except the share of heat demand covered by the fuel cell. The electricity production exceeds the consumption by a factor of 5 and the number of full load hours shows that the fuel cell runs operates almost permanently (Table 4). Despite this 
fact, the fuel cell only covers approximately 30 or 70 percent of the heat demand in the old or new house, respectively.

Table 4: Virtual power plant - spot market, France

Old/new house

\begin{tabular}{ll}
\hline Electricity production & $17559 \mathrm{kWh} / \mathrm{year}$ \\
Full load hours & 8780 \\
Heat demand covered by FC (old/new) & $31 / 68 \mathrm{pct}$. \\
Price premium & $13.3 \mathrm{c} / \mathrm{kWh}$ \\
\hline
\end{tabular}

Source: [27]

As the gas price in France is relatively low, the costs of running the fuel cell for many hours are limited. This gives the fuel cell operating on the spot market an advantage in comparison to the other country cases and the necessary price premium only amounts to $13.3 \mathrm{c} € / \mathrm{kWh}$ taking the investment costs of 5000 $€ / \mathrm{kW}$ into account. This necessary support level is substantially lower than the current support for e.g. solar PV in Germany [34], and a price premium on top of the spot price of electricity seems to be an attractive incentive for residential fuel cells in France.

\subsubsection{Portugal}

As with the French results, as Portugal is represented by French consumption profiles, there is no difference in the technical simulation dependent on house type when the fuel cell is assumed to run as a part of a virtual power plant on the spot market, except for the share of heat demand covered by the fuel cell.

The fuel cell runs almost around the clock and the electricity production is almost $18000 \mathrm{kWh} /$ year (Table 5).

Table 5: Virtual power plant - spot market, Portugal

Old/new house

\begin{tabular}{ll}
\hline Electricity production & $17568 \mathrm{kWh} /$ year \\
Full load hours & 8784 \\
Heat demand covered by FC (old/new) & $31 / 68 \mathrm{pct}$. \\
Price premium & $13.9 \mathrm{c€} / \mathrm{kWh}$ \\
\hline
\end{tabular}

Source: [27]

The spot price of electricity in Portugal is proportionately high, making it more profitable the more hours the fuel cell is running. The necessary price premium is only $13.9 \mathrm{c} € / \mathrm{kWh}$ taking the investment costs of $5000 € / \mathrm{kW}$ into account. A price premium on top of the spot price of electricity seems to be an attractive incentive for residential fuel cells in Portugal.

\subsection{System analysis}

The system analysis provides information on the effects on energy production, fuel consumption, emissions and costs. A reference scenario is devised by the user. The reference scenario is set up to predict the state of development of an energy system at a certain time in the future, usually based on current trends.

The future reference scenarios for Denmark, Portugal and France are based on the DG-TREN forecast for 2030 issued in [29], as well as the 2009 STOA report 
"Future energy systems in Europe" [28]. In order to illustrate the forecasts for the future reference scenario, key figures of the energy systems of the years 2005 and the future reference scenario are compared: The final energy demand in the future reference scenario with regard to fuels is assumed to remain largely constant for all countries; decreasing by 3 pct. in France and Denmark, and increasing by 2 pct. in Portugal. The segmentation of the demand into fuels, or rather energy carriers, in Figure 7 shows that fossil fuels (oil, gas and coal) will still constitute around 50 pct. of the total demand for all countries. The decrease in fossil fuel usage compared to 2005 is mainly achieved by reducing oil demands. In Denmark and France a noticeable increase of 6 pct. can be observed for other fuels, which encompasses mainly renewable resources. Heat demands are slightly decreasing in Denmark and increasing in France and Portugal. Electricity demands are growing in all countries, between 4 pct. and 7 pct. compared to 2005. Figures in the future reference scenario are depicted as percentages with regard to the demand in 2005.

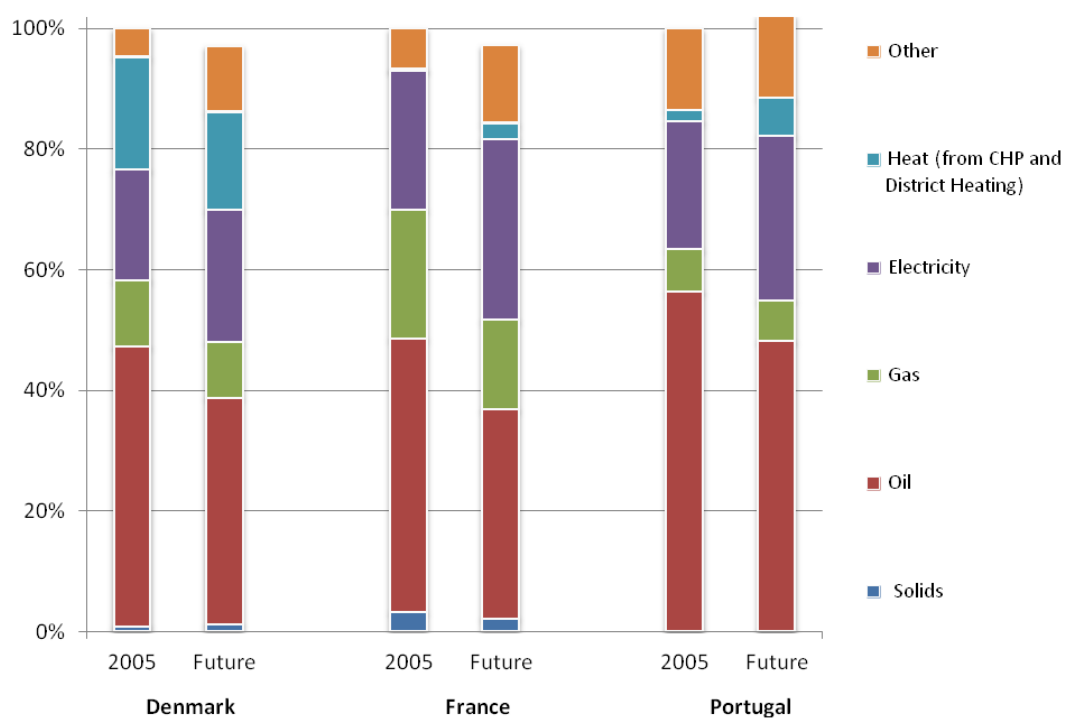

Figure 7: Shares of the final energy demand by fuel for Denmark, Portugal and France, source: [29]

Table 6: Natural gas demand, FC-based microCHP- scenario

\begin{tabular}{lccc} 
& Denmark & France & Portugal \\
\hline National demand (PJ) & 102 & 1810 & 234 \\
Single family house demand (PJ) & 6 & 197 & 10 \\
- share of residential demand (\%) & 64 & 30 & 18 \\
- share of national demand (\%) & 6 & 11 & 4 \\
Single family houses with natural & & & \\
gas boilers (old/new) (1000) & $86.5 / 5.5$ & $2.728 / 372$ & $143 / 19.5$ \\
\hline
\end{tabular}

Note: Different fuel cell scenarios have been analysed for the different countries. Table 7 summarises which scenarios have been analysed for which countries.

Source: [29][35][36][37] 
In order to determine the effects on the energy system, the overall potential for fuel cell based microCHP capacities in each country has to be determined. The aggregated potential for each country is dictated by the natural gas (NG) demand for space heating of all single family detached houses. It is assumed that one microCHP is installed in every single family detached house with access to NG gas. The assumed demands and number of buildings are illustrated in Table 6 .

\begin{tabular}{|c|c|c|c|c|}
\hline & Thermal control & $\begin{array}{c}\text { Thermal control, } \\
\text { peak periods }\end{array}$ & $\begin{array}{c}\text { VPP - } \\
\text { spot market }\end{array}$ & $\begin{array}{l}\text { VPP - regulating } \\
\text { power market }\end{array}$ \\
\hline Denmark & $\begin{array}{l}1 \mathrm{~kW} \\
40 / 90\end{array}$ & & $\begin{array}{l}2 \mathrm{~kW} \\
60 / 80\end{array}$ & $\begin{array}{l}2 \mathrm{~kW} \\
60 / 80\end{array}$ \\
\hline France & $\begin{array}{l}1 \mathrm{~kW} \\
40 / 90\end{array}$ & $\begin{array}{l}1 \mathrm{~kW} \\
40 / 90\end{array}$ & $\begin{array}{l}2 \mathrm{~kW} \\
60 / 80\end{array}$ & \\
\hline Portugal & $\begin{array}{l}1 \mathrm{~kW} \\
40 / 90\end{array}$ & $\begin{array}{l}1 \mathrm{~kW} \\
40 / 90\end{array}$ & $\begin{array}{l}2 \mathrm{~kW} \\
60 / 80\end{array}$ & \\
\hline
\end{tabular}

${ }^{a}$ electrical/overall

Figure 8 illustrates the differences in fuel consumption, costs and $\mathrm{CO}_{2}$ emissions related to energy conversion. There is an overall decrease in fuel consumption for all scenarios. This is however followed by an increase in costs, which is mainly due to the high investment costs of the fuel cells. In France, an increase is seen in the $\mathrm{CO}_{2}$ emissions from energy production as the installed fuel cells substitute nuclear power. Thus, the production of nuclear power (and the use of uranium) decreases and the consumption of natural gas increases. In Denmark and Portugal, slight decreases are found in the emissions of $\mathrm{CO}_{2}$ related to energy conversion. The effects are higher in the VPP-scenarios as the installed capacity is twice as high (Table 7).

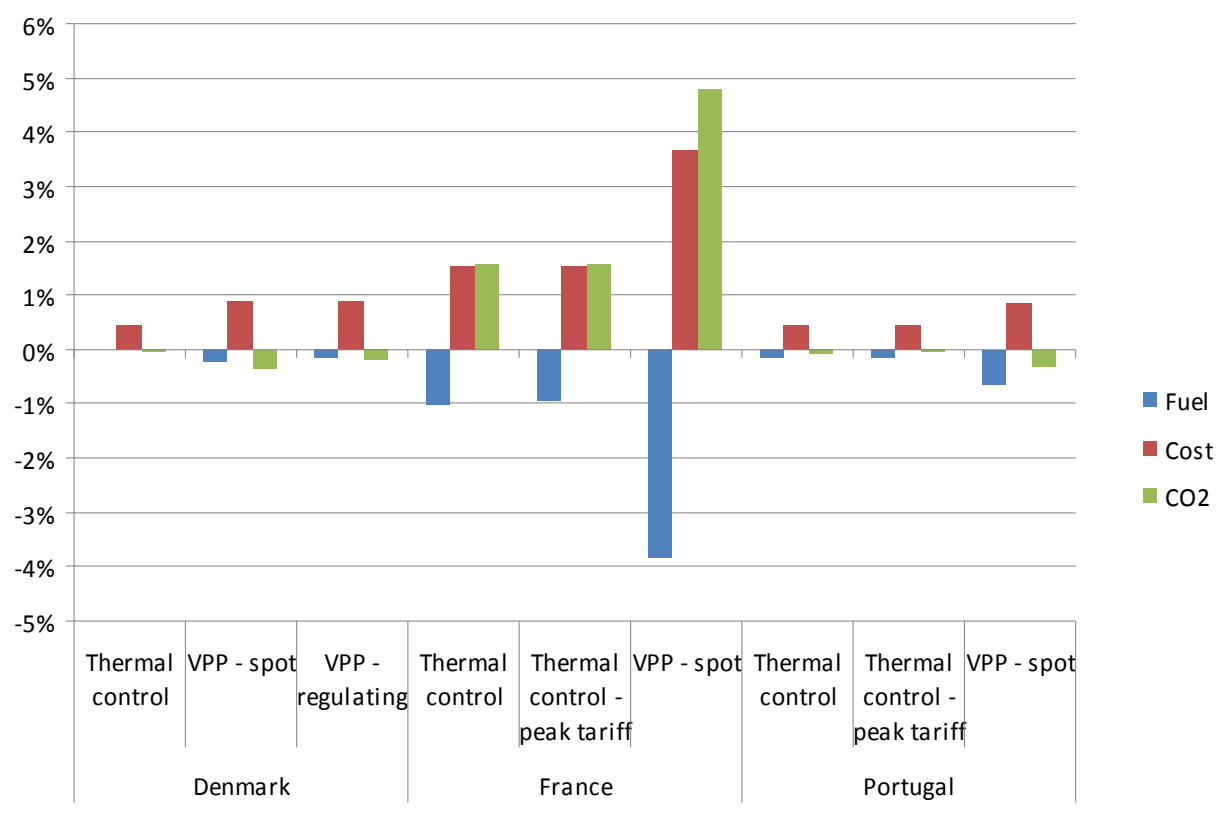

Figure 8: Relative differences in fuel consumption, cost and emissions by country and scenario 
All in all, the results show that the effects of installing the fuel cells mainly depend on the energy system in which they are installed and, secondly, on which operation strategy is used when operating the fuel cells. Installing fuel cells leads to decreased fuel consumption and increased costs in all countries, but only to decreases in $\mathrm{CO}_{2}$ emissions related to energy conversion in Denmark and Portugal. Here the greatest reductions in $\mathrm{CO}_{2}$ emissions are achieved when the fuel cells are operated as virtual power plants due to the higher installed capacities. Although a reduction in $\mathrm{CO}_{2}$ emissions is found in Denmark and Portugal, the $\mathrm{CO}_{2}$ reduction costs - calculated as the increase in costs of the total national energy systems divided by the total decrease in $\mathrm{CO} 2$ emissions - are considerable. The lowest $\mathrm{CO}_{2}$ reduction costs are found in the VPP-spot scenarios (1500 EUR/t in Denmark and 1700 EUR/t in Portugal). The $\mathrm{CO}_{2}$ reduction costs for the thermal control strategies are 3-4 times more expensive. Residential cogeneration fuel cells fuelled by natural gas should hence create other benefits than reduction of $\mathrm{CO}_{2}$ to be feasible. In addition, corresponding reductions in the amount of available $\mathrm{CO}_{2}$ quotas would be required to materialise technical $\mathrm{CO}_{2}$ reductions. This is due to the fact that microCHP units move electricity generation from central power plants that are subject to $\mathrm{CO}_{2}$ quota trading to a non-quota part of the energy system.

\section{Discussion}

The private economic calculations showed that for Denmark net metering would be a promising support mechanism. This is due to a rather high end consumer price and the assumption that the household receives the full end consumer price for the entire amount of electricity produced. In France and Portugal, the virtual power plant on the day-ahead market appears to be a most promising support scheme especially for older building stock In France, the natural gas price is rather low, which gives the fuel cell running many hours a comparative advantage. In Portugal, the electricity spot price is relatively high, thus improving the conditions for the electricity seller. The comparative systems analyses revealed that the virtual power plant scenarios were the most promising, as this would lead to substantial fuel consumption decreases in all countries and $\mathrm{CO}_{2}$ emission reductions in Denmark and Portugal. Due to the large share of nuclear power generation in France, this does not apply for France, but could be achieved by fuel cells using hydrogen indirectly based on nuclear power. In general, the use of fuel cells in virtual power plants is further supported by the actor analysis. However, all scenarios are connected to extensive cost increases. These increases can be met by technological development and scale effects for which there are, according to the SWOT analysis, good chances.

The results obtained are clearly dependent on the assumptions made in the calculations. In order to determine the robustness of the analyses to these assumptions we performed several sensitivity analyses covering the following issues: more than twice as high operation and maintenance costs, a longer lifetime of the fuel cell, shorter (2 years) as well as longer (10 years) lifetime of the stacks, thus covering similar ranges as used in [11] or [21], and finally a higher electricity and gas price increase. The sensitivity analyses gave the 
expected results: longer lifetime of fuel cell as well as stack and a higher spread between gas and electricity prices improved the profitability of the fuel cell, whereas only higher operation costs or maintenance costs, as well as shorter life time of stacks, worsen the profitability. All of the parameters adjusted in the sensitivity analyses moved the results regarding the chosen support scheme in the same direction and did therefore not give rise to changes in the conclusions regarding the choice of support scheme for the three countries.

A few issues were not taken into account in the sensitivity analyses and are discussed in the following:

- The results we obtained for the virtual power plant scenarios show that the fuel cell would be running almost permanently. As we assume that the lifetime is predominantly depending on operating hours, this decreases the lifetime of the fuel cell in years and worsens our results. A precondition generally deteriorating our results is decreased lifetime of the fuel cell. However, our private economic analyses are based on a rather conservative assumption regarding the investment costs, which to a certain extent is assumed to compensate for the abovementioned lifetime effect and possible degradation [15]. On the other hand, it may provide an interesting option for units that are more prone to starts and stops instead of mere operating hours.

- The electricity and gas prices used in the analyses are 2008 prices. The electricity prices in 2008 were relatively high - especially in France. The high electricity price certainly improves the profitability of the fuel cell if the support schemes net metering, feed in tariff with self consumption as well as price premium are assumed. Whether high electricity prices are representative for the future electricity price is debatable. On the one hand, fuel prices, such as oil, gas, coal and bio fuels are assumed to increase, directly or indirectly causing the electricity price to increase. Furthermore, increased electricity consumption tends to drive up the electricity price. On the other hand, an increased RES-E penetration such as wind may further decrease electricity prices. We focused the sensitivity analyses on a common price increase in electricity and gas, which improved the profitability of the fuel cell. We have therefore not analysed the effects of diverging electricity and gas price, nor a common price decrease in electricity and gas.

- The analyses for Portugal were carried out using household consumption data for France due to lacking data availability for the years in analysis. This means that the results for Portugal, especially for the cases driven by thermal demand, only are indicative.

- In the virtual power plant scenarios, there is a substantial amount of blow off for all three countries. We assume this blow off is costless - i.e. there are no additional costs connected to spilling excess heat. A larger heat 
storage would reduce or even eliminate the need for blow off. Furthermore, if the households were provided with larger heat storage, the profitability could improve.

Despite the uncertainties not taken into account in the sensitivity analyses we do find our results robust with regard to the type of support mechanism chosen for the three countries. The results are only showing reason for cautious optimism and the market penetration of fuel cell based microCHP is highly dependent on technological development and price decreases of the fuel cell.

Further assessment of the climate impact could be performed by including the $\mathrm{CO}_{2}$ emissions related to energy conversion as identified through energy system analysis in a life cycle assessment, including all greenhouse gases in all stages of the life cycle. The main climate impact of energy conversion technologies will however normally occur from emitted or avoided $\mathrm{CO}_{2}$ emissions in the energy conversion stage [38].

Finally, the operation analyses and private economic analyses performed in this study also apply to other microCHP technologies such as PEMFC. When defining a support scheme, the eligible technologies need to be defined carefully: a general support mechanism for all mCHP technologies would lead primarily to the deployment of other technologies which are currently cheaper, e.g. gas and Stirling engines, while oversubsidising them by the suggested support levels. This is why a fuel cell technology specific support is recommended, if it is politically desired to develop this technology further by achieving a mCHP market penetration. The technological scope, i.e. whether SOFC systems only or also PEMFC and alternative technologies should be supported, is at the discretion of national policymakers. In the long run, PEMFC systems with hydrogen storage could possibly contribute better to balancing energy systems with a high RES-E penetration than the high-temperature SOFC systems - which in return achieve a higher efficiency.

\section{Conclusions}

The presented study addresses the feasibility of stationary microCHP SOFC fuel cells for the country cases Denmark, France and Portugal. It analyses the interaction of operational strategies and ownership issues and illustrates the support levels required. The different operational strategies are further analysed in an energy systems model, i.e. how they interact with the different national energy systems notably with regard to fuel and CO2 savings and cost-efficiency. To our knowledge, this study is the first one taking a holistic approach covering operational strategies, support schemes and system impacts. More precisely, we find that net metering would be an interesting option for Denmark: the breakeven investment costs equal the assumed investments costs. For France and Portugal, using a large number of microCHP fuel cells as a virtual power plant for operating it according to spot market pricing seems promising: the price premium required is low in comparison with the support required under alternative policy schemes. For heat-driven scenarios, approximately 5000 operating hours occur in the majority of cases. Already a comparatively small 
heat storage of 100-200 litres can limit the number of cold starts required considerably. For the electricity-led cases, operation is hardly ever profitable without support. Furthemore, in France, the scheme induces a growth of the natural gas consumption and an increase of the $\mathrm{CO} 2$ emissions which is against the French energy policy targeting more independency from fossil fuels and a reduction by 4 of its $\mathrm{CO} 2$ emission by 2050 . This is in line with the findings by [8], who mention a buyback rate of $6 \mathrm{p} / \mathrm{kWh}$ as the border where the microCHP unit generates in baseload hours due to the high export value from the house.

The system integration analysis reveals that the impact of fuel cells is highly dependent on the energy system it is placed in: $\mathrm{CO}_{2}$ emission reductions related to energy conversion are only achieved for the Danish and Portuguese cases. In France the fuel cells primarily replace nuclear power and thus actually increase the $\mathrm{CO}_{2}$ emissions related to energy conversion. Costs increase in all cases, but the fuel and $\mathrm{CO}_{2}$ savings effect in Denmark and Portugal are more pronounced if the microCHP fuel cells are operated as a virtual power plant.

While [7] focuses on heat-driven operation under existing support schemes, we put forward policy scheme suggestions and required national levels and thus, extend previous work [6,39]. Regarding systems integration, [4] stress that the dynamic operation of fuel cells to respond to variations of intermittent generation is important. However, we find that first, already at modest price premium levels, an extraordinarily high number of full load operating hours is reached. Thus, the response incentive is rather limited. Second, we analysed one case where we operated a $2 \mathrm{~kW}$ virtual power plant partially on the regulating power market to reflect intermittent system requirements. This case was financially inferior to pure spot market operation because a share of generation capacity is kept as a backup for a limited number of hours where it can be used. However, in the long run, we think that fast response could become a core goal when developing microCHP SOFC units. In the short run, scale effects and efficient deployment can best be reached with a large number of full load hours and long stack lifetimes (in line with [11]).

If the promotion of microCHP fuel cells is regarded as a political goal and a first step on the way to the application of fuel cells also for other applications at a later stage, we suggest that specific support schemes should be introduced soon. These would be lower - in some cases notably lower - than the support given to photovoltaic units in its early days. After approximately 10 years, support mechanisms providing a stable investment framework have led this technology close to grid parity in a number of countries. However, a range of other, currently more cost-competitive microCHP options, is already available on the market. The long-term potential of fuel cell applications therefore needs to be regarded when taking a possible support decision.

\section{Acknowledgements}

The FC4Home project (Socio-Economic and Energy Systems Analysis of Micro Combined Heat and Power (Fuel Cell Technology), www.fc4home.com) is supported by the HY-CO ERA-NET scheme (Reference 001/2008) and funded by 
the Danish Energy Agency (Denmark), ADEME (France) and the Science and Technology Foundation (Portugal), for which we are grateful. The sole responsibility for the contents of this document lies with the authors and does not represent the opinions of the funding organisations.

\section{References}

[1] European Commission, 2011. Proposal for a Directive of the European Parliament and of the Council on energy efficiency and repealing Directives 2004/8/EC and 2006/32/EC. COM (2011) 370 final.

[2] Meibom P, Karlsson K. Role of hydrogen in future North European power system in 2060. Int J Hydrogen Energy 2010; 35:1853-63.

[3] Krewitt W, Nitsch J, Fischedick M, Pehnt M, Temming H. Market perspectives of stationary fuel cells in a sustainable energy supply system long-term scenarios for Germany. Energy Policy 2006; 34:793-803.

[4] Mathiesen BV, Østergaard PA, Solid oxide fuel cells and large-scale integration of intermittent renewable energy. In: Mathiesen BV. Fuel cells and electrolysers in future energy systems. PhD thesis, Department of Development and Planning, Aalborg University, 2008, Appendix II: 29-45.

[5] Hawkes AD, Leach MA, On policy instruments for support of micro combined heat and power. Energy Policy 2008; 36:2973- 82.

[6] Schroeder ST, Costa A, Obé E. Support schemes and ownership structures - the policy context for fuel cell based micro-combined heat and power, J Power Sources 2011;196:9051-7.

[7] Erdmann, G. Future economics of the fuel cell housing market. Int J Hydrogen Energy 2003; 28:685 - 94.

[8] Hawkes AD, Leach MA, Cost-effective operating strategy for residential micro-combined heat and power, Energy 2007; 32:711-23.

[9] De Paepe M, Mertens D, Combined heat and power in a liberalised energy market. Energy Conv Man 2007; 48:2542-55.

[10] Briguglio N, Ferraro M, Brunaccini G, Antonucci V. Evaluation of a low temperature fuel cell system for residential CHP. Int J Hydrogen Energy 2011; 36:8023-9.

[11] Staffell I, Green R, Kendall K. Cost targets for domestic fuel cell CHP. J Power Sources 2008; 181:339-49.

[12] Colella W. Design options for achieving a rapidly variable heat-topower ratio in a combined heat and power (CHP) fuel cell system (FCS). J Power Sources 2002; 106:388-96.

[13] De Paepe M, D'Herdt P, Mertens D. Micro-CHP systems for residential applications. Energy Conv Man 2006; 47:3435-46.

[14] Hawkes AD, Brett DJL, Brandon NP. Fuel cell micro-CHP technoeconomics: Part 1 - model concept and formulation. Int J Hydrogen Energy 2009; 34:9545-57.

[15] Hawkes AD, Brett DJL, Brandon NP. Fuel cell micro-CHP technoeconomics: Part 2 - Model application to consider the economic and environmental impact of stack degradation. Int J Hydrogen Energy 2009; 34:9558-69.

[16] Farhad S, Hamdullahpur F, Yoo Y. Performance evaluation of different configurations of biogas-fuelled SOFC micro-CHP systems for residential applications. Int J Hydrogen Energy 2010; 35:3758-68. 
[17] Staffell I, Green RJ. Estimating future prices for stationary fuel cells with empirically derived experience curves. Int J Hydrogen Energy 2009; 34:5617-28.

[18] Costa A, Kroff P. National Cases combining promotion scheme, ownership structure and operational strategy for Denmark, France and Portugal. FC4home project, Work Package 6 report, 2011.

[19] Huber A. Residential fuel cell micro CHP in Denmark, France and Portugal: Analyzing actor perceptions. Work Package 2 report(www.fc4home.com)

[20] Ropenus S, Schröder ST, Costa A and Obé E. Support Schemes and Ownership structures - The Policy Context for Fuel Cell Based MicroCombined Heat and Power, Work Package 1 Report, 2010 (www.fc4home.com)

[21] Hawkes A, Leach M. Solid oxide fuel cell systems for residential micro-combined heat and power in the UK: Key economic drivers. J Power Sources 2005;149:72-83.

[22] Mathiesen BV. Fuel cells and electrolysers in future energy systems. PhD thesis, Department of Development and Planning, Aalborg University, 2008.

[23] Fuel Cell Bulletin. CFCL BlueGen units for virtual power plant project in Netherlands. July 2012.

[24] Föger K. Challenges in Commercialising an Ultraefficient SOFC Residential Generator. Presentation by CFCL at the IPHE Workshop on Stationary Fuel Cells, Tokyo, 2011.

[25] CFCL. BlueGEN - modular generator - powertheat. Product brochure by the manufacturer, http://www.bluegen.info/Assets/Files/BlueGen\%20Brochure Architects -web.pdf (19.09.2012)

[26] Koetter E, Obé E. Residential fuel cell micro CHP in Denmark, France and Portugal: Results simulation analysis. FC4home project Work Package 5 Report (www.fc4home.com)

[27] Pade L, Schröder ST, Münster M and Morthorst PE: Residential fuel cell micro CHP in Denmark, France and Portugal. Analyses of models for promotion schemes and ownership arrangements. FC4home project Work Package 4 Report (www.fc4home.com). ISBN 978-87-92706-37-9

[28] Larsen G, Schmidt OB. Future Energy Systems in Europe. The Danish Board of Technology, Copenhagen, 2009

[29] Capros P, Mantzos L, Tasios N, De Vita A,Kouvaritakis N. EU energy trends to 2030 - Update 2009. Publications Office of the European Union, Luxembourg, 2010. ISBN 978-92-79-16191-9

[30] ENTSO-E, European Network of Transmission System Operators for Electricity. [Online] [Cited: February 12, 2011.$]$ https://www.entsoe.eu/resources/data-portal/country-packages/

[31] Mathiesen BV, Münster M, Fruergaard T. Uncertainties related to the identification of the marginal energy technology in consequential life cycle assessments. Journal of Cleaner Production 2009 0ct;17(15):13318. 
[32] Münster M, Meibom P. Long-term affected energy production of waste to energy technologies identified by use of energy system analysis. Waste Management 2010 Dec;30(12):2510-9.

[33] DONG Energy. Typical household electricity consumption. Available (19.01.2012): www.dongenergy.dk/privat/energiforum/tjekditforbrug/typiskelforbrug ¿Pages/hus.aspx

[34] EEG 2000. German Act on Granting Priority to Renewable Energy Sources (Renewable Energy Sources Act) from March 29th, 2000.

[35] Danish Statistics. Housing Statistics (http://www.dst.dk/) [Cited: June 2011]

[36] Meijer F, Itard L, Sunikka-Blank M. Comparing European residential building stocks: performance, renovation and policy opportunities. Building Research and Information, 2009; 37(5): 533 -551.

[37] Portuguese Directorate General for Energy and Geology. Energy Statistics (http://www.dgeg.pt/) [Cited: June 2011]

[38] Pehnt M. Environmental impacts of distributed energy systems The case of micro cogeneration. Environmental Science \&amp; Policy 2008 Feb;11(1):25-37.

[39] Pade L, Schröder ST. Fuel cell based micro-combined heat and power under different policy frameworks - an economic analysis. Energy Conv Man, in press.

\begin{tabular}{|c|c|c|c|c|}
\hline \multicolumn{2}{|c|}{$\begin{array}{l}\text { Appendix A: Choice of control } \\
\text { Denmark, France and Portugal }\end{array}$} & \multicolumn{3}{|c|}{ strategies and support schemes for } \\
\hline & & Support scheme & Capacity & Efficiency $^{\mathrm{a}}$ \\
\hline \multirow[t]{2}{*}{ DK } & Thermal control & Net metering/FIT & $1 \mathrm{~kW}$ & $40 / 90$ \\
\hline & VPP - spot/reg. power market & Price premium & $2 \mathrm{~kW}$ & $60 / 80$ \\
\hline \multirow[t]{3}{*}{ FR } & Thermal control & Net metering//FIT/FITS & $1 \mathrm{~kW}$ & $40 / 90$ \\
\hline & Thermal control, peak periods & FIT/FITS & $1 \mathrm{~kW}$ & $40 / 90$ \\
\hline & VPP - spot market & Price premium & $2 \mathrm{~kW}$ & $60 / 80$ \\
\hline \multirow[t]{3}{*}{ PT } & Thermal control & FITS & $1 \mathrm{~kW}$ & $40 / 90$ \\
\hline & Thermal control, peak periods & Net metering & $1 \mathrm{~kW}$ & $40 / 90$ \\
\hline & VPP - spot market & Price premium & $2 \mathrm{~kW}$ & $60 / 80$ \\
\hline
\end{tabular}

a electrical/overall 